Білик Олена Іванівна кандидат економічних наук, доцент кафедри адміністративного і фінансового менеджменту Національного університету «Львівська політехніка», вул. Ст. Бандери 28а,5-й н.к., кім. 2-б, м. Львів, 79013, тел.: (097) 289-68-88, e-mail: olena.bilyk@gmail.com, https://orcid.org/0000-0002-7110-7257

Хім Марія Кімсанівна асистент кафедри адміністративного i фінансового менеджменту, Національного університету «Львівська політехніка», вул. Ст. Бандери 28а,5-й н.к., кім. 2-б, м. Львів, 79013, тел.: (097) 289-68-88, e-mail: Mariya.K.Khim@lpnu.ua, https://orcid.org/0000-7000$3151-6435$

\title{
ПОВЕДІНКОВИЙ АНАЛІЗ ЯК ОДИН ІЗ КЛЮЧОВИХ ФАКТОРІВ ОЦІНКИ ЕФЕКТИВНОСТІ РОБОТИ ДЕРЖАВНИХ СЛУЖБОВЦІВ
}

Анотація. В цій статті авторками проведено аналіз поведінки державних службовців та ії взаємозв'язок з рівнем ефективності їхньої роботи. Описано професіографічну та психографічну модель діяльності держслужбовців. Представлено модель визначення виду нематеріальних мотивів, що формує основу для поведінкового аналізу державних службовців і включає експериментальний аналіз їхньої поведінки шляхом визначення пріоритетів для різних вікових груп. Досліджено психологічні процеси та механізми формування неетичної поведінки державних службовців, в яких мотиваційна боротьба та психологічний дисбаланс $є$ двома ключовими психологічними станами, а також запропоновано перелік питань з варіантами відповіді, які визначатимуть напрям поведінки державного службовця на початку роботи.

Проведено практичне дослідження поведінки (методика «Шкала можливостей та потреб») та проведено порівняльний аналіз оцінки ефективності роботи державних службовців до і після впровадження даної методики. За методикою «Оцінка ділових та особистих якостей» складено портрет державного службовця до і після здійснення розстановок та розподілу ролей. За результатами проведеного регресійного аналізу було виділено три групи факторів, котрі можуть впливати на поведінку державних службовців.

Розроблено модель поведінкового аналізування державних службовців, що включає систему критеріїв оцінки, відповідність яким буде сприяти підвищенню ефективності роботи та управлінської культури, зростання довіри населення до інституту місцевого самоврядування та представників інших рівнів і гілок владної ієрархії.

Результати проведеного дослідження стали приводом для перегляду 
системи управління людськими ресурсами, зокрема в сфері державної служби. Застосований аналіз поведінки може допомогти основним дослідникам у розробці зовнішньо валідних експериментів і тим самим посилити теоретичне значення базових досліджень для розуміння поведінки державних службовців. Прикладні дослідження 3 людьми, спрямовані на культурно важливі проблеми, допоможуть покращити імідж державної служби в Україні та мінімізувати ряд ризиків, які можуть спричинити до послаблення довіри до державних інститутів.

Ключові слова: поведінковий аналіз, методи поведінкового аналізування, модель поведінкового аналізування державні службовці, ділові та особистісні якості, ефективність роботи.

Bilyk Olena Ivanivna Ph.D. in Economy, Associate Professor, Associate Professor of the Administrative and Financial Management Department, Lviv Polytechnic National University, 28a Stepan Bandera St., Building 5, 2-b Room, Lviv, 79013, tel.: (097) 289-68-88, e-mail: olena.bilyk@gmail.com, https://orcid.org/0000-0002-7110-7257

Khim Mariia Kimsanivna Assistant of the Administrative and Financial Management Department, Lviv Polytechnic National University, 28a Stepan Bandera St., Building 5, 2-b Room, Lviv, 79013, tel.: (097) 289-68-88, e-mail: Mariya.K.Khim@1pnu.ua, https://orcid.org/0000-7000-3151-6435

\section{BEHAVIORAL ANALYSIS AS ONE OF THE KEY FACTORS FOR EVALUATION OF THE EFFICIENCY OF CIVIL SERVANTS}

Abstract: The article analyzes the behavior of civil servants and its relationship with the level of efficiency of their work. The professional and psychographic model of civil servants' activity is described. The model of determining the type of intangible motives is presented, which forms the basis for the behavioral analysis of civil servants and includes experimental analysis of their behavior by determining priorities for different age groups. The psychological processes and mechanisms of formation of unethical behavior of civil servants, in which motivational struggle and psychological imbalance are two key psychological states, are studied, as well as a list of questions with answer options that will determine the direction of civil servant behavior at the beginning.

A practical study of behavior (methodology "Scale of Opportunities and Needs") and a comparative analysis of the evaluation of the effectiveness of civil servants before and after the implementation of this methodology were proposed. According to the method of "Assessment of business and personal qualities" a portrait of a civil servant before and after the placement and distribution of roles was made. According to the results of the regression analysis, three groups of factors that may influence the behavior of civil servants were identified.

A model of behavioral analysis of civil servants has been developed, which includes a system of evaluation criteria, compliance with which will increase 
efficiency and management culture, increase public confidence in the institution of local self-government and representatives of other levels and branches of government.

The results of the study led to a review of the human resources management system, in particular in the civil service.

Applied behavior analysis can help key researchers to develop externally valid experiments and thus enhance the theoretical significance of basic research for understanding the behavior of civil servants. Applied research focused on culturally important issues will help improve the image of the civil service in Ukraine and minimize a number of risks that may lead to a weakening of trust in public institutions.

Keywords: behavioral analysis, methods of behavioral analysis, model of behavioral analysis, civil servants, business and personal qualities, work efficiency.

Постановка проблеми. Державна служба як соціально-правовий інститут займає особливе місце в досягненні загальнонаціональних цілей $\mathrm{i}$ відіграє важливу роль у механізмі управління державою. Для виконання своїх професійних обов'язків державний службовець повинен не тільки володіти професійними знаннями, але мати певний набір поведінкових рис і особистісних якостей, необхідних для здійснення професійної діяльності. Поведінка державних службовців та посадових осіб місцевого самоврядування має забезпечувати довіру суспільства до державної служби та служби в органах місцевого самоврядування [1].

Поведінка державних службовців та посадових осіб місцевого самоврядування грунтується на принципах державної служби та служби в органах місцевого самоврядування, визначених Законами України «Про державну службу» [2] і «Про службу в органах місцевого самоврядування» [3], а також загальних вимогах до поведінки цих осіб, визначених Законом України «Про запобігання корупції» [4]. Дотримання усіх цих правил та вимог державними службовцями напряму пов'язана 3 рівнем ефективності їхньої роботи.

Взаємозв'язок громадянина 3 державним службовцем потребує урегулювання поведінки публічного службовця. В умовах повномасштабної інтеграції до європейських стандартів це питання стає осердям подальшого розвитку державної служби зокрема і публічної служби загалом.

Тривалий час домінуючим підходом до аналізу поведінки державних службовців було припущення про їх раціональність. Проте емпіричні дослідження накопичували все більше свідчень про те, що для державних службовців характерною $є$ наявність систематичних відхилень від раціональної поведінки в процесі прийняття рішень. Їх врахування $\epsilon$ важливим для державотворчих процесів та для кожного громадянина зокрема. Застосування поведінкового аналізу значною мірою забезпечить виявлення загрози неетичної поведінки державних службовців, що зумовило необхідність проведення цього дослідження. 
Аналіз останніх досліджень і публікацій. Вперше про аналіз поведінки людини згадується в ранніх теоріях біхевіоризму. Засновником «класичного», психологічного біхевіоризму вважають американського психолога Д. Вотсона. Вчений вперше згадує про поведінку у 1913 році у своїй статті «Psychology as the Behaviorist Views It» [5], яку інколи називають «Маніфестом біхевіоризму». Поведінка, як психологічне явище пов'язана із працями Б. Скінера [6], Р. Коуза [7, 8, 9]. Е. Доунса [10], Дж. Бьюкенена [11] та М. Олсона [12], де описуються реакції поведінки людей. Тому 3 початку 50-х років минулого століття поступова трансформація теорії біхевіоризму у комплексне поняття поведінки та методів іiі аналізування, що пізніше матимуть місце в сферах державного та корпоративного управління, фінансах, економіці, стратегічному плануванні, оборонній політиці тощо. На початку 70-х років методи аналізування поведінки цієї теорії встигли проникнути у інструментарії економіки та політичної науки. У 90-х роках минулого століття американським економістом Р.Талером було розроблено модель аналізу поведінкових механізмів лібертаріанського патерналізму, котра відкрила великі можливості для підвищення ефективності при розробці та реалізації державних політик [13].

Питання визначення рівнів розвитку особистісних властивостей i якостей розглядаються в роботах О. Плєшакової, К. Озиміної [14], С. Л. Рубінштейна [15] та ін. Спробу пов'язати наявний досвід дослідження людини в праці 3 деякими новими для психології праці проблемними питаннями, що стосуються, зокрема, поведінки зробили Н. Пряжников на О. Пряжникова [16]. Роботи цих учених утворили необхідну методологічну базу, але в той же час багато аспектів проблеми поведінки державних службовців та медодів ії аналізу потребують додаткових досліджень.

В навчальних посібниках з питань державної служби та державного управління (С. Дубенко, Т. Желюк, В. Малиновський, Ю. Оболенський) представлені проблеми відповідності поведінки державного службовця його обов'язкам. О.Оболенський, як автор навчального посібника «Державна служба», розглядає поведінку державних службовців і iї формування в контексті державної служби як культурного інституту суспільства [17, с.283].

Експериментальний аналіз поведінки державних службовців, шляхом визначення виду нематеріальних мотивів досліджено у працях

Малімон Л. [18]. Поведінковий підхід до лідерства на державній службі розкрито у праці Литвиновського Є. та Литвиновської І. [19].

На сьогодні поведінковий аспект ефективності роботи державних службовців у дослідженнях вітчизняних науковців недостатньо розкрито, існуючі практики здійснення реалізації та розробки моделей поведінки державних службовців не відповідають вимогам часу та $є$ методологічно застарілими. Крім того, в Україні відсутня нормативно-правова база яка б могла регулювати використання поведінкових механізмів у сфері управління державою, що і обумовлює актуальність цієї проблеми.

До того ж, специфічність вітчизняних умов державотворення, невизначеність і нестабільність політичної ситуації не дозволяють повною 
мірою перенести західні теорії і досвід на український грунт, проте сприяють науковому пошуку розроблення $\mathrm{i}$ впровадження вітчизняної моделі застосування механізмів поведінкового аналізу державних службовців.

Усвідомлення практичної значущості розв’язання проблеми формування ефективного державного управління орієнтує на подальший пошук не тільки теоретичного підгрунтя, а й практичних рекомендацій щодо адаптації поведінкових механізнів державного службовця до сучасних українських реалій.

Метою статті є аналіз поведінки державних службовців та дослідження iii впливу на ефективність їхньої роботи, розроблення моделі поведінкового аналізування державних службовців, надання рекомендацій щодо удосконалення системи управління людськими ресурсами, зокрема в сфері державної служби.

Виклад основного матеріалу. Уся професійна діяльність дердавного службовця може бути зведена до двох основних характеристик: 1) система цінностей, які відстоюються та утверджуються в суспільстві; 2) спеціальні уміння та знання, а також риси характеру, які притаманні представникам певної професії. «Вирішальним для успіху всіх державних установ, їх інструментів $\epsilon$ професійний та етичний рівень державних службовців», наголошує професор О. Люхтерхандт, - даючи експертну оцінку Концепції адміністративної реформи в Україні. «Усе залежить від їх готовності та здатності уявляти себе на службі «не володарями», а слугами i розпорядниками загальних громадянських та державних інтересів i відповідним чином підпорядковувати їм свої приватні інтереси і потреби» [20, с. 92].

Грунтуючись на емпіричних дослідженнях, суть поведінки державного службовця полягає у дотримання правил моральної та професійної етики в практичній діяльності державного службовця, що включає моральний вигляд фахівця, розуміння і здійснення вимог професійної етики, вміння керуватися універсальними та професійними моральними нормами. Результатом дослідження стало обгрунтування побудови професіограми та психограми, які включають опис основних параметрів (рис, характеристик) державного службовця, $\mathrm{i}$ вибудовує професійно-психографічну модель його діяльності.

\section{Таблиця 1}

\section{Професіограма державного службовця}

\begin{tabular}{|l|l|}
\hline Загальна & Державний службовець - це особа, яка призначається або \\
(опис професії) & обирається на державну посаду, працює в органах місцевого \\
чи державного управління. \\
Державна служба - це публічна, професійна, політично \\
неупереджена діяльність із практичного виконання завдань і \\
функцій держави, зокрема щодо [1]: \\
- надання якісних адміністративних послуг. \\
- вироблення й аналізу публічної політики, основ та \\
технологій прийняття управлінських рішень. \\
- розв’язування складних задач публічного управління та
\end{tabular}




\begin{tabular}{|c|c|}
\hline & 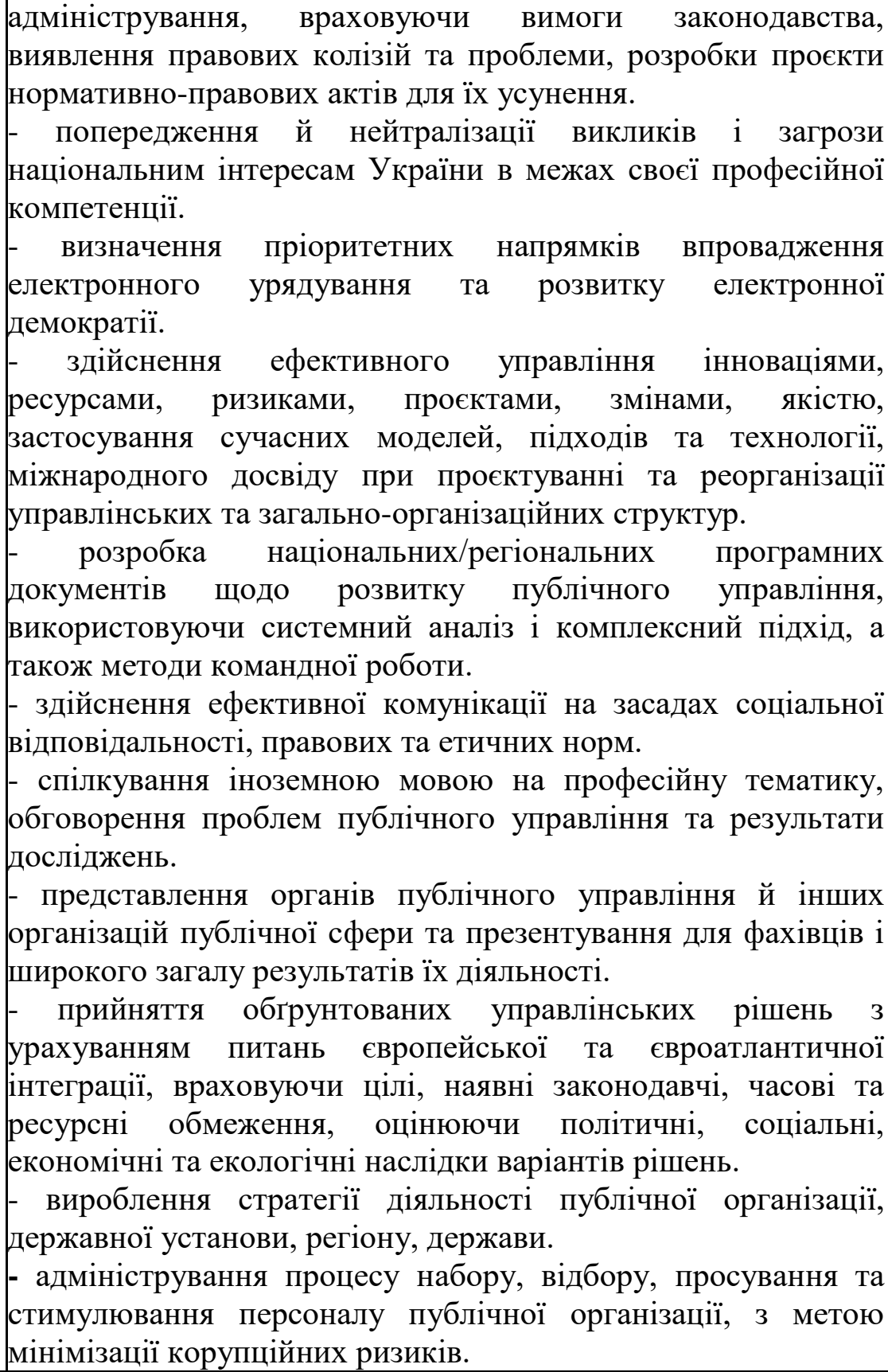 \\
\hline Умови праці & $\begin{array}{l}\text { Інструменти та продукти праці: інформаційно-аналітичні } \\
\text { інструменти, системи підтримки прийняття та реалізації } \\
\text { управлінських рішень, спеціалізоване } \\
\text { забезпечення. } \\
\text { Кабінетна та зальна системи планування робочих місць, } \\
\text { приміщення, котре відповідає виконуваним функціям. }\end{array}$ \\
\hline Професійні знання & $\begin{array}{l}\text { Знання нормативно-правової бази, принципів i } \\
\text { закономірностей функціонування системи публічного } \\
\text { управління та адміністрування як сукупності інститутів } \\
\text { державного управління, місевого самоврядування, } \\
\text { громадянського суспільства відповідно до покладених на них } \\
\text { функцій і повноважень; відносин, явищ, процесів, моделей та } \\
\text { механізмів, що характеризують прояви публічного } \\
\text { управління та адміністрування на вищому, центральному, } \\
\text { регіональному та місцевому рівнях. }\end{array}$ \\
\hline
\end{tabular}




\begin{tabular}{|c|c|}
\hline Професійні вміння & 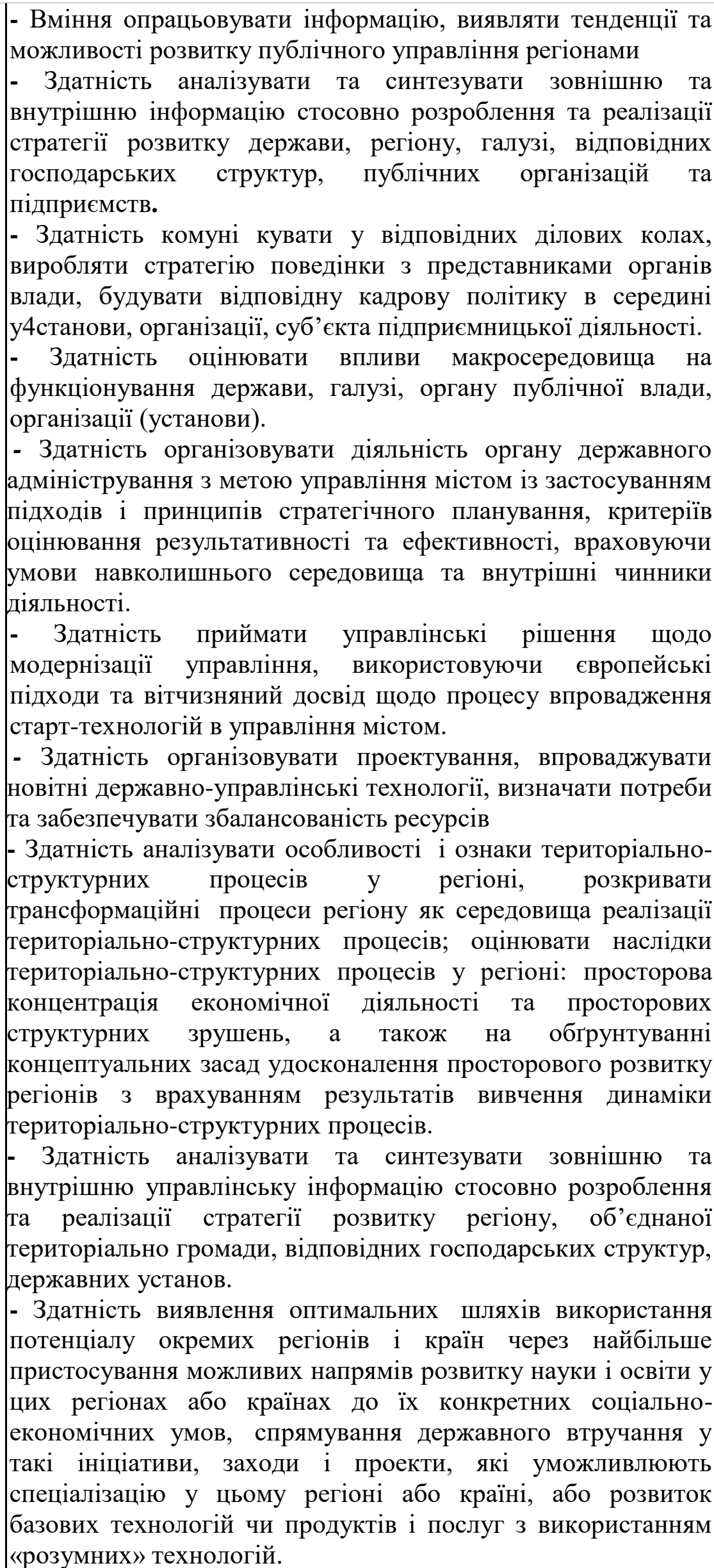 \\
\hline
\end{tabular}




\begin{tabular}{|c|c|}
\hline & 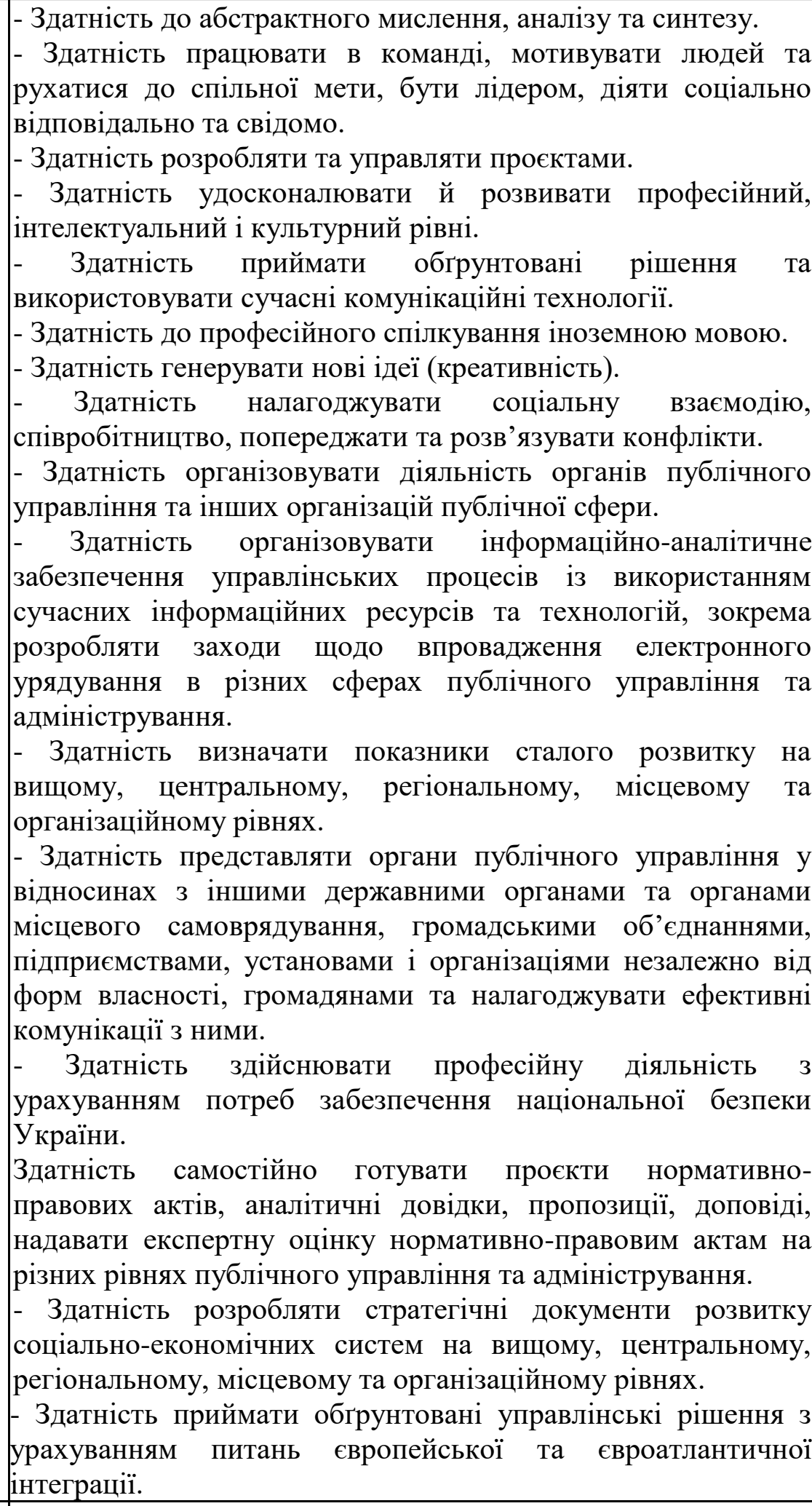 \\
\hline $\begin{array}{l}\text { Перспективи } \\
\text { кар'єрного росту }\end{array}$ & $\begin{array}{l}\text { Можливість управлінського кар’єрного просування: } \\
\text { - на посадах в центральних і місцевих органах державної влади; } \\
\text { - на посадах в органах місцевого самоврядування; } \\
\text { на посадах в структурах недержавних суб’єктів } \\
\text { громадянського суспільства та громадських організацій; } \\
\text { - на керівних посадах і посадах фахівців на підприємствах, } \\
\text { установах і організаціях державної і комунальної форм власності; } \\
\text { на управлінських і адміністративних посадах в в } \\
\text { міжнародних організаціях та їх представництвах в Україні. }\end{array}$ \\
\hline
\end{tabular}




\begin{tabular}{|c|c|}
\hline Затребуваність & Затребувані на ринку праці на постійній основі. \\
\hline \multirow[t]{2}{*}{ Мотивація } & Мотивація - $\quad$ це $\quad$ процес \\
\hline & $\begin{array}{l}\text { вибору державним службовцем того чи іншого типу } \\
\text { поведінки, що визначається комплексним впливом зовнішніх } \\
\text { (стимули) і внутрішніх (мотиви) чинників. }\end{array}$ \\
\hline Стимулювання & $\begin{array}{l}\text { Стимулювання праці передбачає створення умов, за яких } \\
\text { активна трудова діяльність дає певні, раніше зафіксовані } \\
\text { результати, стає необхідною і достатньою умовою } \\
\text { задоволення } \quad \text { значних і } \text { соціально обумовлених } \\
\text { потреб державного службовця, формування у нього мотивів } \\
\text { до праці. }\end{array}$ \\
\hline
\end{tabular}

Складенота сформовано авторами на основі джерела [21]

Звичайно, що поведінка державного службовця як регулятора чиновницького корпусу має сприяти зростанню ефективності його роботи. Проте, окрім поведінки, важливими $є$ i особистісні якості державного службовця, що зумовило необхідність побудови психограми державного службовця (табл.2).

Таблиия 2

\section{Психограма державного службовця}

\begin{tabular}{|c|c|}
\hline $\begin{array}{l}\text { Група психологічних } \\
\text { якостей }\end{array}$ & Характеристики психологічних якостей \\
\hline $\begin{array}{l}\text { Якості, що } \\
\text { забезпечують } \\
\text { успішність виконання } \\
\text { професійної діяльності } \\
\text { - професійно важливі } \\
\text { якості }\end{array}$ & $\begin{array}{l}\text { - хороші організаторські здібності (тверда воля, } \\
\text { цілеспрямованість, рішучість, наполегливість, творчий підхід); } \\
\text { - уміння керувати; } \\
\text { - комунікативні здібності (уміння налагоджувати контакт, } \\
\text { налагоджувати взаємини, розвиненість каналів вербального і } \\
\text { невербального спілкування, загальна професійна } \\
\text { компетентність); } \\
\text { - здатність керувати собою (здатність до саморегуляції в процесі } \\
\text { самоврядування і рефлексії); } \\
\text { - вміння виявлти ділові якості підприємця: ставити перспективні } \\
\text { цілі, використовувати сприятливі можливості; } \\
\text { - добре розвинені аналітичні здібності (уміння одержувати й } \\
\text { обробляти потрібну інформацію, оцінювати, порівнювати та } \\
\text { засвоювати ії). }\end{array}$ \\
\hline $\begin{array}{l}\text { Особистісні якості, } \\
\text { інтереси та схильності }\end{array}$ & $\begin{array}{l}\text { - ерудованість, енергійність; } \\
\text { - зовнішня привабливість (охайність, елегантність, гарні манери, } \\
\text { вихованість, чітка, ясна і жива мова); } \\
\text { - впевненість у собі та прийнятих рішеннях; } \\
\text { - цілеспрямованість (пріоритет мотивів організаторської } \\
\text { діяльності); } \\
\text { - терплячість; } \\
\text { - тактовність (здатність виявляти почуття міри і знаходити }\end{array}$ \\
\hline
\end{tabular}




\begin{tabular}{|l|l|}
\hline & найкращу форму взаємодії); \\
& - вимогливість; \\
& - критичність (уміння виявити та підкреслити вагомі для \\
діяльності відхилення від встановлених норм); & - гнучкість (здатність гнучко реагувати на різні зміни в \\
& управлінських ситуаціях); \\
& - креативність (уміння творчо підходити до вирішення \\
управлінських завдань, схильність до імпровізації); & - наявність розвиненої інтуїції; \\
& - прагнення до постійного особистісного росту; \\
\hline Якості, що & - низький рівень розвитку чи відсутність організаторських і \\
перешкоджають & комунікативних здібностей; \\
ефективності & - невпевненість в собі, нерішучість; \\
професійної діяльності & - неорганізованість, недисциплінованість, безініціативність; \\
& - безпринципність, відсутність почуття обов'язку; \\
& - неврівноваженість, безтактність; \\
& - відсталість, невміння, небажання змінюватися та змінювати \\
поведінку під впливом навколишнього середовища; \\
\\
- схильність перекладати відповідальність на інших.
\end{tabular}

\section{Примітка: Складено та сформовано авторами}

Професійна етика державних службовців є відображенням іміджу влади та соціальної моралі, тому поєднання зазначених у таблицях 1 та 2 професійних та особистісних характеристик $\epsilon$ визначальним для розвитку державного службовця та державної служби загалом. Хороша професійна етика державних службовців допомагає уряду встановити довіру. У той же час, за належної професійної етики, державні службовці здатні неупереджено розглядати справи, виконувати свої обов'язки та надавати кращі послуги населенню.

Професійна етика державних службовців, як основна частина соціальної моральної конструкції, позитивно впливає на стабільний розвиток соціальної економіки та політики.

Побудова професійної етики державних службовців $є$ визначальним для їх власного розвитку. Робота державних службовців та урядових відомств має ставати більш прозорою та справедливою, а також посилено покарання за корупційну поведінку державних службовців. Для кар'єрного розвитку 
державних службовців вигідно встановлювати належну професійну етику.

Саме застосування інноваційних методів сприяння мотивації впливатиме на розвиток державного службовця як особистості, так і державної служби загалом. 3 цією метою в дослідженні пропонується застосування методів поведінкового аналізу, тобто аналізу поведінки людей, опираючись на біологічні та експериментальні фактори. Кінцевою метою поведінкового аналізу є встановлення та підвищення соціально важливої поведінки у роботі державних службовців. Застосований аналіз поведінки може допомогти основним дослідникам у розробці зовнішньо валідних експериментів і тим самим посилити теоретичне значення базових досліджень для розуміння поведінки державних службовців. Прикладні дослідження 3 людьми, спрямовані на культурно важливі проблеми, допоможуть покращити імідж державної служби в Україні та мінімізувати ряд ризиків (н.п., корупційних), які можуть спричинити до послаблення довіри до державних інститутів. Архітектура і логіка дослідження вибудована 3 позиції аналізу поведінки державного службовця за різними критеріями, методологія визначення яких представлена нижче i полягає у визначенні пріоритетності видів нематеріальних мотивів за окремими напрямками із вказанням вікової структури державних службовців.

Результатом емпіричного дослідження стала побудова моделі визначення виду нематеріальних мотивів, що формує основу для поведінкового аналізу державних службовців і включає експериментальний аналіз їхньої поведінки шляхом визначення пріоритетів для різних вікових груп. На рисунку 1. представлено модель використання експериментального методу поведінкового аналізу, застосовуваного для можливості визначення впливу на поведінку державних службовців нематеріальної мотивації. Саме в розрізі надання державними службовцями послуг, нематеріальна мотиваціє відграє ключову роль, адже це полегшить аналіз поведінки державного службовця. 


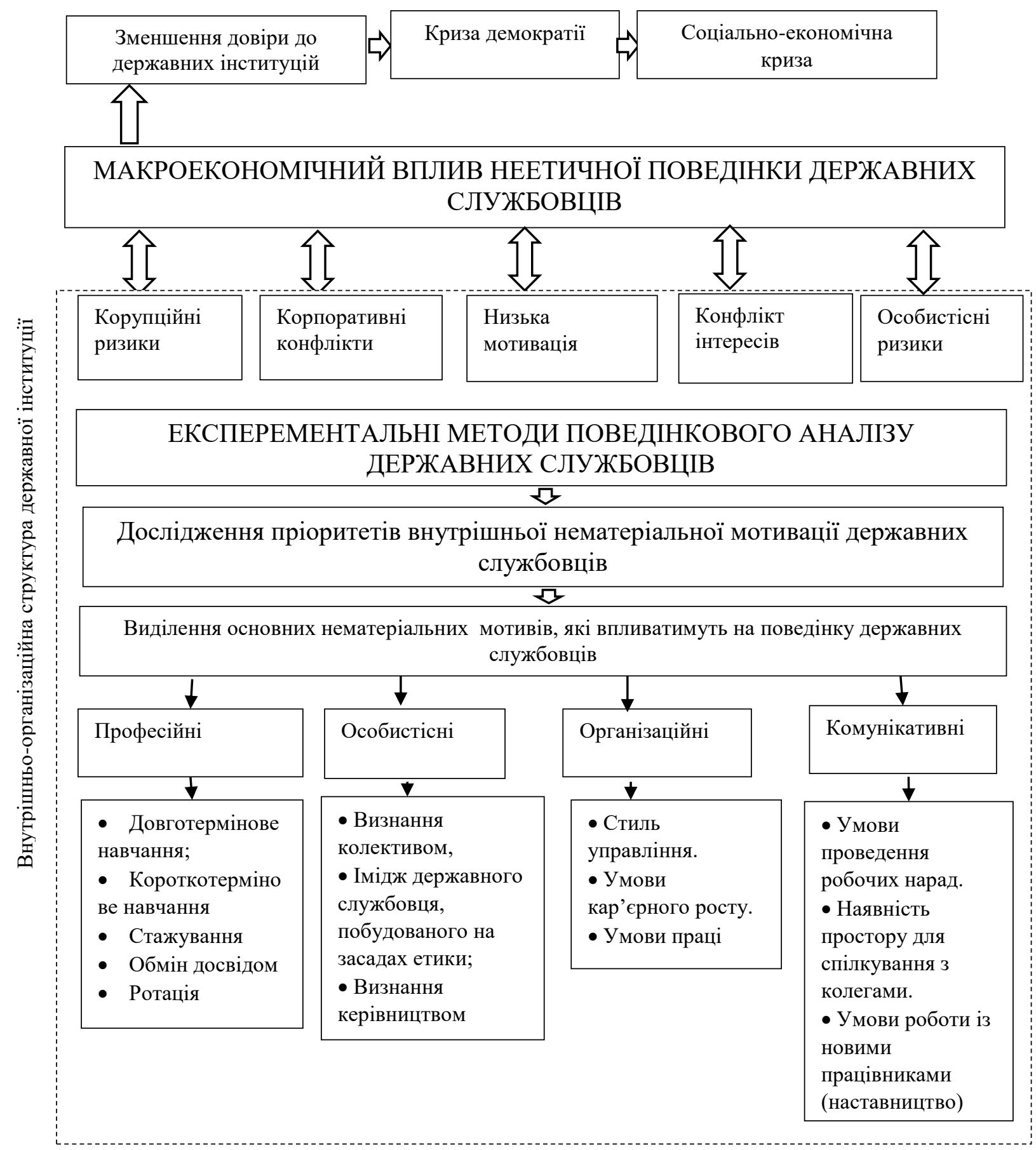

Puc.1. Модель визначення виду нематеріальних мотивів

Примітка: складено та сформовано авторами

Зазначена модель застосування експериментального методу поведінкового аналізу державних службовців була реалізована шляхом внесення її в опитуванні через Google Форми і спрямована на періодичний внутрішній аудит із виявленням пріоритетів серед запропонованих нематеріальних мотивів за основними групами, а також i за окремими напрямками із вказанням вікової структури державних службовців. Результати структури нематеріальних мотивів подано на рисунку 2. 


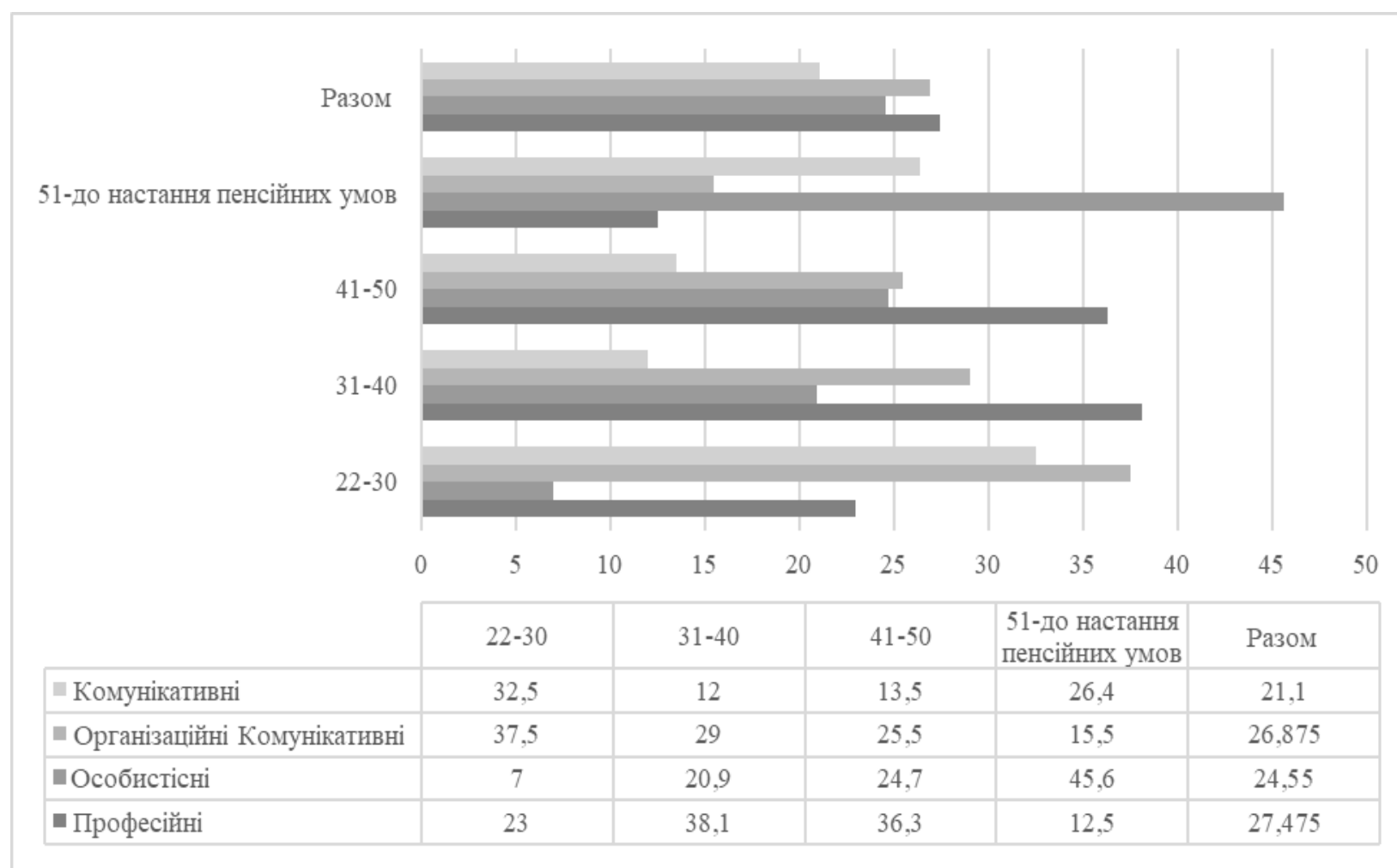

Pис.2. Аналіз пріоритетів за основними групами за віковою структурою державних службовиів

Примітка: Складено та сформовано авторами

Таким чином, для мінімізації представлених на рисунку 1 ризиків за допомогою виділення основних видів нематеріальних мотивів слід враховувати і вікову структуру державних службовців, що дасть можливість раннього подолання настання ризиків.

Наступним напрямком у пропонованій методиці є більш глибший аналіз чинників, які впливають на поведінку державних службовців. Існують певні психологічні процеси та механізми формування неетичної поведінки державних службовців, в яких мотиваційна боротьба та психологічний дисбаланс $є$ двома ключовими психологічними станами.

Неетична поведінка державних службовців полягає у постійній психологічній деструкції через професійну етику, закони та правила. Психологічна боротьба з неетичною поведінкою часто займає більше часу, ніж інші загальні способи поведінки. Після психологічної боротьби державні службовці відчуватимуть психологічний дисбаланс через різницю між фактичним та очікуваним рівнем. Якщо цей психологічний дисбаланс не вдається стримати, державні службовці формують неправильну психологічну мотивацію, яка сприяє розвитку корупції. Неетична поведінка, така як корупція державних службовців, принесла суспільству нестабільність та дисгармонію.

На рисунку 3 представлено основні причини корупції серед державних службовців. 


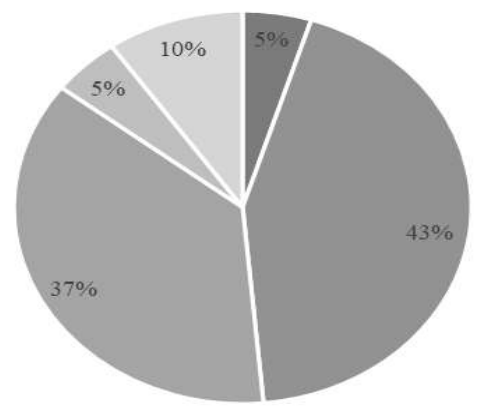

\section{Рис.3. Причини корупиії серед державних службовиів}

Примітка: Складено та сформовано авторами на основі джерела [22]

Важливим для розвитку державного службовця є мотивація на початку роботи в державній службі, що дасть можливість запобігти неетичній поведінці державних службовців та мінімізувати корупційні ризики. Так у таблиці 3 пропонуємо перелік питань 3 варіантами відповіді, які визначатимуть напрям поведінки державного службовця.

Таблиия 3

\section{Анкета питань для державних службовців - початківців}

\begin{tabular}{|c|c|c|c|}
\hline $\begin{array}{l}\text { № } \\
\Pi / \Pi\end{array}$ & Питання & Варіанти відповіді & Опис \\
\hline \multirow[t]{4}{*}{1.} & \multirow{4}{*}{$\begin{array}{c}\text { Чи вважаєте Ви, що } \\
\text { професійна етика } \\
\text { важлива для } \\
\text { державних } \\
\text { службовців? }\end{array}$} & А. дуже важливо (4 бали) & \multirow{4}{*}{$\begin{array}{c}\text { Можна здійснити аналізування } \\
\text { структурно, вибираючи певну групу } \\
\text { осіб, або ж персонально }\end{array}$} \\
\hline & & $\begin{array}{l}\text { Б. Посереднє значення } \\
\text { (3 бали) }\end{array}$ & \\
\hline & & $\begin{array}{l}\text { В. Непринципове значення } \\
\text { (2 бали) }\end{array}$ & \\
\hline & & Г. Немає значення (1 бал) & \\
\hline \multirow[t]{4}{*}{2.} & \multirow{4}{*}{$\begin{array}{c}\text { Яким є ваш план } \\
\text { кар'єри, ставши } \\
\text { державним } \\
\text { службовцем? }\end{array}$} & $\begin{array}{l}\text { A. Не робити помилок } \\
\text { (2 бали) }\end{array}$ & \multirow{4}{*}{$\begin{array}{c}\text { Можна здійснити аналізування } \\
\text { структурно, вибираючи певну } \\
\text { групу осіб, або ж персонально, } \\
\text { запропонувавши встановити } \\
\text { пріоритети, що дасть можливість } \\
\text { змалювати «портрет» державного } \\
\text { службовця }\end{array}$} \\
\hline & & Б. Зручні умови праці (1 бал) & \\
\hline & & $\begin{array}{l}\text { В. Виконувати вказівки } \\
\text { керівництва (3 бали) }\end{array}$ & \\
\hline & & $\begin{array}{c}\text { Г. Розвиватися професійно } \\
\text { (4 бали) }\end{array}$ & \\
\hline \multirow[t]{3}{*}{3.} & \multirow{3}{*}{$\begin{array}{c}\text { Яким рівнем } \\
\text { державного } \\
\text { службовця Ви } \\
\text { вважаєте, що можете } \\
\text { стати? }\end{array}$} & $\begin{array}{c}\text { А. на посадах державної } \\
\text { служби категорії "А" } \\
\text { (3 бали) }\end{array}$ & \multirow{3}{*}{$\begin{array}{c}\text { Можна здійснити аналізування } \\
\text { структурно, вибираючи певну } \\
\text { групу осіб, або ж персонально } \\
\text { (дасть можливість проаналізувати } \\
\text { професійні амбіції державного } \\
\text { службовця і якщо співставити з } \\
\text { питанням 2- то це дасть здійснити } \\
\text { аналізування про кваліфікаційні } \\
\text { можливості того, кого анкетуємо) }\end{array}$} \\
\hline & & $\begin{array}{l}\text { Б. на посадах державної } \\
\text { служби категорії "Б" } \\
\text { (4 бали) }\end{array}$ & \\
\hline & & $\begin{array}{c}\text { В. на посадах державної } \\
\text { служби категорії "В" } \\
\text { (2 бали) }\end{array}$ & \\
\hline
\end{tabular}




\begin{tabular}{|c|c|c|c|}
\hline \multirow[t]{4}{*}{4.} & \multirow{4}{*}{$\begin{array}{c}\text { Коли у Вас } \\
\text { виникне конфлікт з } \\
\text { колегою, } \\
\text { Ви. }\end{array}$} & $\begin{array}{l}\text { А. для Вас це не має } \\
\text { значення (2 бали); }\end{array}$ & \multirow{4}{*}{$\begin{array}{c}\text { Можна здійснити аналізування } \\
\text { структурно, вибираючи певну групу } \\
\text { осіб, або ж персонально }\end{array}$} \\
\hline & & $\begin{array}{c}\text { Б. Будете ігнорувати колегу } \\
\text { (3 бали) }\end{array}$ & \\
\hline & & $\begin{array}{c}\text { В. Ви будете почуватися } \\
\text { засмученим та небажаним } \\
\text { на роботі (1 бал); } \\
\end{array}$ & \\
\hline & & $\begin{array}{c}\text { Г. Проаналізує ситуацію, } \\
\text { щоб зрозуміти,чия це вина. } \\
\text { (4 бали) } \\
\end{array}$ & \\
\hline \multirow[t]{4}{*}{5.} & \multirow{4}{*}{$\begin{array}{l}\text { Чому Ви вирішили } \\
\text { стати державним } \\
\text { службовцем? }\end{array}$} & $\begin{array}{c}\text { А. здобути владу і стати } \\
\text { вищим чиновником (1 бал) }\end{array}$ & \multirow{4}{*}{$\begin{array}{c}\text { Можна здійснити аналізування } \\
\text { структурно, вибираючи певну групу } \\
\text { осіб, або ж персонально (дасть } \\
\text { можливість проаналізувати } \\
\text { професійні а амбіції державного } \\
\text { службовця і якщо співставити з } \\
\text { питаннями 2, 3- то це дасть здійснити } \\
\text { аналізування про } \\
\text { кваліфікаційні можливості того, } \\
\text { кого анкетуємо }\end{array}$} \\
\hline & & $\begin{array}{c}\text { Б. стабільна зарплата і } \\
\text { комфортна в житті(2 бали) }\end{array}$ & \\
\hline & & $\begin{array}{c}\text { В. підходить для моєї } \\
\text { особистості (3 бали) }\end{array}$ & \\
\hline & & $\begin{array}{c}\text { Г. робота для людей } \\
\text { (4 бали) }\end{array}$ & \\
\hline \multirow[t]{4}{*}{6.} & \multirow{4}{*}{$\begin{array}{l}3 \text { яким із наведених } \\
\text { тверджень ви } \\
\text { погоджуєтесь? }\end{array}$} & $\begin{array}{l}\text { А. гроші - це найважливіше } \\
\text { (2 бали); }\end{array}$ & \multirow{4}{*}{$\begin{array}{c}\text { Можна здійснити аналізування } \\
\text { структурно, вибираючи певну групу } \\
\text { осіб, або ж персонально }\end{array}$} \\
\hline & & $\begin{array}{l}\text { Б. професіоналізм - це } \\
\text { найважливіше (4 бали) }\end{array}$ & \\
\hline & & $\begin{array}{l}\text { В. робити хорошу роботу - } \\
\text { це найважливіше (3 бали) }\end{array}$ & \\
\hline & & Г. не має значення (1 бал) & \\
\hline \multirow[t]{4}{*}{7.} & \multirow{4}{*}{$\begin{array}{c}\text { Як оцінити ситуацію, } \\
\text { коли державні } \\
\text { службовці } \\
\text { дорікаються об'єктом } \\
\text { обслуговування, але } \\
\text { вс одно мають мати } \\
\text { гарне ставлення? }\end{array}$} & \begin{tabular}{|c|}
$\begin{array}{c}\text { А. втрата самооцінки, я сам } \\
\text { цього ніколи не буду робити } \\
(2 \text { бали) }\end{array}$ \\
\end{tabular} & \multirow[t]{4}{*}{$\begin{array}{c}\text { Можна здійснити аналізування } \\
\text { структурно, вибираючи певну групу } \\
\text { осіб, або ж персонально }\end{array}$} \\
\hline & & $\begin{array}{c}\text { Б. не можна дати відсіч } \\
\text { об'єкту обслуговування, } \\
\text { але не потрібно підтримувати } \\
\text { гарне ставлення (4 бали); }\end{array}$ & \\
\hline & & $\begin{array}{l}\text { В. незалежно від відповіді, } \\
\text { коментарів немає(3 бали); }\end{array}$ & \\
\hline & & $\begin{array}{c}\text { Г. Я думаю, що буду робити } \\
\text { те саме(1 бал) }\end{array}$ & \\
\hline \multirow[t]{4}{*}{8.} & \multirow{4}{*}{$\begin{array}{c}\text { Як оцінити } \\
\text { керівника, який } \\
\text { часто звинувачує } \\
\text { підлеглих? }\end{array}$} & $\begin{array}{l}\text { А. здатний зрозуміти цю } \\
\text { ситуацію(2 бали); }\end{array}$ & \multirow{4}{*}{$\begin{array}{c}\text { Можна здійснити аналізування } \\
\text { структурно, вибираючи певну групу } \\
\text { осіб, або ж персонально }\end{array}$} \\
\hline & & $\begin{array}{l}\text { Б. погана практика, може мати } \\
\text { негативний вплив на } \\
\text { психологію підлеглих(4 бали); }\end{array}$ & \\
\hline & & $\begin{array}{c}\text { В. керівник завжди правий } \\
\text { i завжди зможе відновити } \\
\text { власну репутацію (1 бал) } \\
\end{array}$ & \\
\hline & & $\begin{array}{l}\text { Г. стійкий до такої } \\
\text { поведінки (3 бали) }\end{array}$ & \\
\hline
\end{tabular}




\begin{tabular}{|c|c|c|}
\hline \multicolumn{3}{|c|}{ ШКАЛА КРИТЕРІЇВ } \\
\hline 1 & 30-32 балів & $\begin{array}{c}\text { Високі цінності державного службовця, високий } \\
\text { рівень розуміння суті державної служби і свого місця } \\
\text { в ній, системне дотримання етичної поведінки } \\
\text { державного службовця. Пріоритетом є максимальна } \\
\text { сумлінність, престиж і професіоналізм }\end{array}$ \\
\hline 2 & 25-29 балів & $\begin{array}{c}\text { Високі цінності державного службовця, достатнє } \\
\text { розуміння суті державної служби і свого місця в ній, } \\
\text { знання і зрідка - недотримання етичної поведінки } \\
\text { державного службовця. Пріоритетом є високий } \\
\text { професіоналізм }\end{array}$ \\
\hline 3 & 17-24балів & $\begin{array}{c}\text { Наявні цінності, характерні державному } \\
\text { службовцю, присутнє розуміння суті державної } \\
\text { служби і свого місця в ній. Часто недотримання } \\
\text { етичної поведінки державним службовцем. } \\
\text { Пріоритетом є індивідуалізм та імідж державного } \\
\text { службовця } \\
\text { салы }\end{array}$ \\
\hline 4 & 8-16 балів & $\begin{array}{c}\text { Низький рівень цінностей, характерних державному } \\
\text { службовцю, здеформоване розуміння суті державної } \\
\text { служби і свого місця в ній. Часто недотримання } \\
\text { етичної поведінки державним службовцем. } \\
\text { Пріоритетом є наявність влади і можливість } \\
\text { покращити своє матеріальне становище }\end{array}$ \\
\hline
\end{tabular}

Примітка: Складено та сформовано авторами

У поєднанні поведінкового аналізу державних службовців та результатів практичного розслідування професійної етики державних службовців легко виявити та нейтралізувати внутріорганізаційні ризики. Слід наголосити на дослідженні особистості та моралі при прийомі на роботу державних службовців для побудови професійної етики державних службовців, а також проводити планомірне та організоване навчання 3 професійної етики. Слід посилити керівництво професійними цінностями та професійною мотивацією державних службовців, щоб виявити і ліквідувати неетичні професійні цінності, такі як індивідуалізм, прагнення збагатитися нелегально та бюрократія. Норми професійної поведінки та професійні ролі молодих державних службовців повинні культивуватися шляхом трудової практики, щоб під контролем мас та суспільства можна було вибудувати належну професійну етику. Також необхідно врахувати і пріоритетність нематеріальних мотивів для інших вікових груп державних службовців, що дозволить задовольнити їхні психологічні потреби, що сприятиме формуванню траєкторії їхньої поведінки.

Одним 3 основних, найважливіших чинників ефективної діяльності державного службовця є бажання і готовність виконувати свої обов'язки. Що стосується розумової праці, то ця проблема досі залишається нерозкритою, що зумовлює необхідність використання окремих методик дослідження. Тому пропонується використаня методики «Шкала можливостей і потреб» та «Оцінка ділових якостей», які застосовуються мережею продуктивного мислення The Performance Thinking Network - глобальною спільнотою людей та організацій. Ці методи поведінкового аналізування сприяють розумінню, 
комунікації та покращенню людської діяльності [23]. Так, було виявлено основні поведінкові характеристики, які мають прямий вплив на ефективність роботи державних службовців та було застосовано ці характеристики як оптимальні практичних рішення. Практичне дослідження поведінки державних службовців проводилося в період з жовтня 2020 року по квітень 2021 року. У дослідженні взяли участь 46 державних службовців, які навчаються на базі Національного університету «Львівська політехніка» (керівники -6 осіб, помічники, радники - 14 осіб, фахівці - 26 осіб). Після завершення процесу відбору співробітників на конкретну посаду, було визначено шкали можливостей і потреб [23]. Провівши опитування було виявлено різницю між результатами до і після застосування запропонованої методики.

На рисунку 4 чітко показано думку опитаних, які вважають, що виросла можливість використовувати повністю свої нинішні вміння i знання. Найбільше зросла можливість розробляти власні ідеї, оскільки при чіткому визначенні зони відповідальності і власної сфери діяльності, робота співробітників придбала структурований і упорядкований характер, що в свою чергу дозволило, заощадити багато часу на обдумування і генерування своїх ідей.

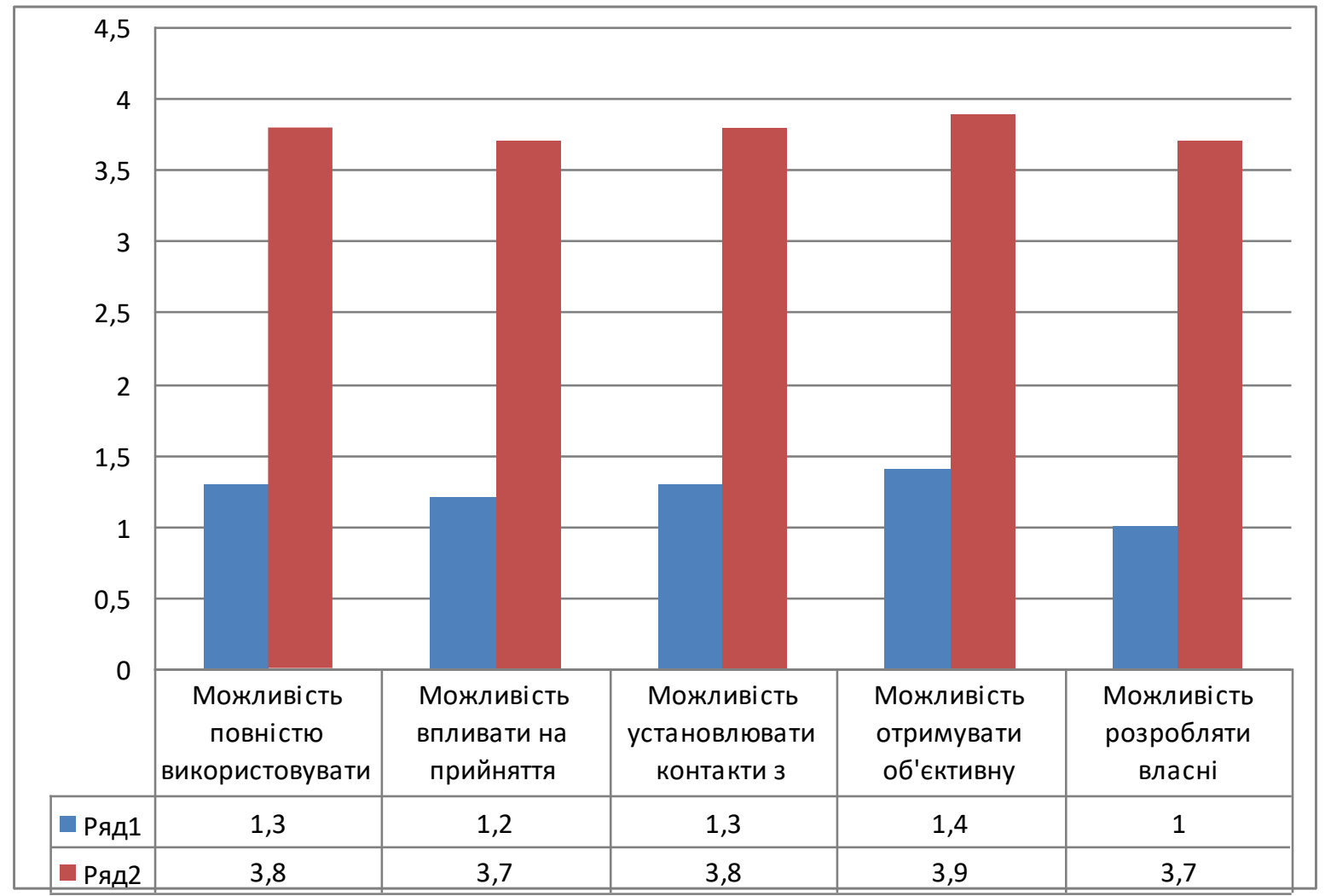

Puс. 4. Порівняльний аналіз найбільш змінених факторів за методикою «Шкала можливостей і потреб».

Примітка: Складено та сформовано авторами на основі джерела [23]

При чіткій оцінці ефективності роботи кожного державного службовця певного рангу, конкретно визначивши критерії його оцінки, зросла 
можливість створити хорошу професійну репутацію. Одним 3 новітніх чинників стала можливість встановлення контактів 3 працівниками різних посадових рівнів.

Через декілька тижнів після першого опитування, державних службовців було опитано за методикою «Оцінка ділових та особистих якостей» (таблиця 4) $\mathrm{i}$ складено приблизний портрет державних службовців до i після здійснення розстановок та розподілу ролей. (таблиця 4.1, рисунок 5).

Табличя 4

Методика «Оцінка ділових та особистих якостей»

\begin{tabular}{|c|c|c|c|c|c|c|}
\hline № & КРИТЕРІЇ & \multicolumn{5}{|c|}{ ШКАЛА } \\
\hline 1. & Вміння дотримуватись слова & 1 & 2 & 3 & 4 & 5 \\
\hline 2. & Чесність і правдивість & 1 & 2 & 3 & 4 & 5 \\
\hline 3. & Оперативність під час прийняття рішень & 1 & 2 & 3 & 4 & 5 \\
\hline 4. & Емоційна стійкість & 1 & 2 & 3 & 4 & 5 \\
\hline 5. & Самооцінка & 1 & 2 & 3 & 4 & 5 \\
\hline 6. & Толерантність & 1 & 2 & 3 & 4 & 5 \\
\hline 7. & Психологічна спрямованість & 1 & 2 & 3 & 4 & 5 \\
\hline 8. & Ініціативність & 1 & 2 & 3 & 4 & 5 \\
\hline 9. & Самоприйняття & 1 & 2 & 3 & 4 & 5 \\
\hline 10. & Творчий підхід до справи & 1 & 2 & 3 & 4 & 5 \\
\hline 11. & Здатність до самовдосконалення та розвитку & 1 & 2 & 3 & 4 & 5 \\
\hline 12. & Поведінкова гнучкість & 1 & 2 & 3 & 4 & 5 \\
\hline 13. & Націленість на результат & 1 & 2 & 3 & 4 & 5 \\
\hline 14. & Емпатія & 1 & 2 & 3 & 4 & 5 \\
\hline 15. & Моральні якості & 1 & 2 & 3 & 4 & 5 \\
\hline 16 & Врівноваженість & 1 & 2 & 3 & 4 & 5 \\
\hline 17 & Поведінкова стратегія & 1 & 2 & 3 & 4 & 5 \\
\hline
\end{tabular}

Примітка: 5 балів - даний критерій є характерним і відображається у всіх випадках на 100\%; 4 бали - даний критерій проявлясться у всіх випадках у середньому на 75\%; 3 бали - - даний критерій відображається у всіх випадках у середньому на 50\%; 2 бали - - даний критерій відображається у всіх випадках у середньому на 25\%; 1 бал - - даний критерій ніколи не проявляється 0\%

Складено та сформовано авторами на основі джерела [23]

Таблиия 4.1

\section{Порівняльний аналіз середнього значення показників оцінки ділових i особистих якостей державних службовців до і після здійснення розстановок та розподілу ролей}

\begin{tabular}{|c|c|c|c|}
\hline № & Критерії & $\begin{array}{c}\text { Середній показник до } \\
\text { впровадження } \\
\text { методики }\end{array}$ & $\begin{array}{c}\text { Середній показник після } \\
\text { впровадження методики }\end{array}$ \\
\hline 1. & Вміння дотримуватись слова & 3,5 & 4,2 \\
\hline 2. & Чесність і правдивість & 2,4 & 3,5 \\
\hline 3. & $\begin{array}{c}\text { Оперативність під час прийняття } \\
\text { рішень }\end{array}$ & 2,9 & 4,1 \\
\hline 4. & Емоційна стійкість & 2,1 & 3,5 \\
\hline 5. & Самооцінка & 2,7 & 3,8 \\
\hline 6. & Толерантність & 2,1 & 2,8 \\
\hline 7. & Психологічна спрямованість & 3,5 & 4,6 \\
\hline 8. & Ініціативність & 2,4 & 4,4 \\
\hline 9. & Самоприйняття & 3,8 & 3,5 \\
\hline
\end{tabular}




\begin{tabular}{|c|c|c|c|}
\hline 10. & Творчий підхід до справи & 3,1 & 3,9 \\
\hline 11. & $\begin{array}{c}\text { Здатність до самовдосконалення та } \\
\text { розвитку }\end{array}$ & 2,4 & 3,3 \\
\hline 12. & Поведінкова гнучкість & 1,8 & 2,9 \\
\hline 13. & Націленість на результат & 3,1 & 4,1 \\
\hline 14. & Емпатія & 2,2 & 3,8 \\
\hline 15. & Моральні якості & 2,9 & 4,1 \\
\hline 16. & Врівноваженість & 3,4 & 3,6 \\
\hline 17. & Поведінкова стратегія & 3,5 & 3,6 \\
\hline
\end{tabular}

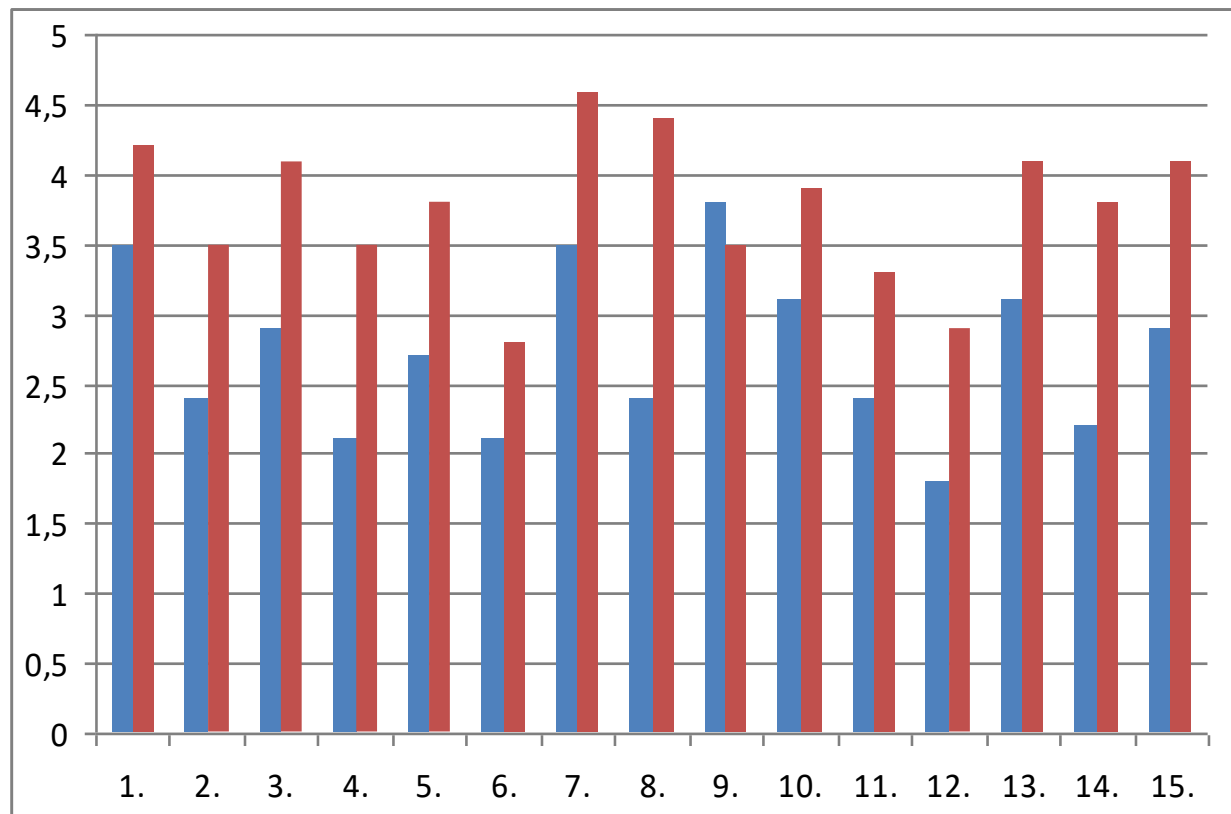

Pис. 5 Порівняльний аналіз середніх показників критеріїв оцінки ділових $i$ особистих якостей державних службовців до і після здійснення розстановок та розподілу ролей

Примітка: Складено та сформовано авторами на основі джерела [23]

Першою чергою, варто підкреслити, що після проведених досліджень та впровадження зазначених методик [23] спостерігається зростання майже усіх показників. Так, після впровадження удосконаленої системи оцінки ефективності різко зросла оперативність у прийнятті управлінських рішень, що своєю чергою, спрощує пошук відповідального співробітника в конкретній ситуації, яка вимагає оперативного вирішення. Підвищилися критерії енергійності і працездатності, оскільки співробітники почали уникати внутріорганізаційних конфліктів, а також витрачати робочий час на визначення зон відповідальності кожного співробітника, що підвищило продуктивність і якість роботи.

За результатами таблиці 4 додатково було виділено три групи факторів, котрі можуть впливати на покращення даних показників: фактор «саморегуляції», що включає в себе емоційну стійкість, толерантність та врівноваженість, фактор «ефективності та адаптивності соціальних контактів», що складається з самооцінки, самоприйняття і поведінкової гнучкості, фактор «орієнтованості на інших», що включає в себе психологічну спрямованість, поведінкову стратегію і емпатію.

Результати регресійного аналізу показують, що найбільшу вагу в 
структурі поведінки державних службовців мають емоційна стійкість, поведінкова гнучкість, самосприйняття, толерантність. Дещо меншу вагу виявлено у психологічної спрямованості, врівноваженості, емпатії, поведінкової стратегії. Показник самооцінки лежить нижче лінії регресії, тобто його вага в структурі поведінки мінімальна. Зв'язок поведінки державних службовців зі статтю, віком і статусом не виявився, тобто їх поведінка не залежить від даних характеристик (Таблиця 5).

Таблиия 5

Результати регресійного аналізу

\begin{tabular}{|l|l|l|l|}
\hline Компоненти & $\begin{array}{l}\text { коефіцієнт } \\
\text { регресії }\end{array}$ & $\begin{array}{l}\text { B-коефіцієнт } \\
\text { параметра (Beta) }\end{array}$ & $\begin{array}{l}\text { рівень } \\
\text { значущості }\end{array}$ \\
\hline Емпатія & 0,129 & 0,133 & $\mathbf{p} \leq 0,01$ \\
\hline Поведінкова гнучкість & 0,208 & 0,211 & $\mathrm{p} \leq 0,001$ \\
\hline Психологічна спрямованість & 0,133 & 0,148 & $\mathrm{p} \leq 0,001$ \\
\hline Толерантність & 0,262 & 0,182 & $\mathrm{p} \leq 0,001$ \\
\hline Самосприйняття & 0,168 & 0,194 & $\mathrm{p} \leq 0,001$ \\
\hline Врівноваженість & 0,539 & 0,146 & $\mathrm{p} \leq 0,01$ \\
\hline Емоційна стійкість & 0,869 & 0,244 & $\mathrm{p} \leq 0,001$ \\
\hline Поведінкова стратегія & 1,226 & 0,130 & $\mathrm{p} \leq 0,001$ \\
\hline
\end{tabular}

Примітка: Складено та сформовано авторами

Здійснене дослідження дало підству для уніфікації ключових показників поведінкового аналізування всіх державних службовців категорій Б та В та розробки моделі поведінкового аналізування державних службовців.

Для розробки моделі поведінкового аналізування усім державним службовцям категорій Б та В слід призначити ключові показники поведінкового аналізування (таблиця 6). Державні службовці у своїй діяльності керуються принципами етики державної служби, що грунтуються на положеннях Конституції України, законодавства про державну службу та запобігання корупції. Проте, пропонуємо ввести формулу, яка б включала ще корегувальні коефіцієнти, побудовані на основі врахування неправомірних дій державними службовцями, виведену на основі опитування 10 експертів щодо найчастіших випадків відхилень від норм поведінки (до складу експертів увійшли: 3 докторів наук 3 державного управління, 2 працівників - державних службовців категорії В служби управління персоналом, 3 працівників - державних службовців категорії Б, 2 працівників служби управління персоналом державного органу):

Таблиия 6

Модель поведінкового аналізування державних службовців

\begin{tabular}{|l|l|c|c}
\hline $\begin{array}{l}\text { Умовне } \\
\text { позначення }\end{array}$ & $\begin{array}{l}\text { Показник поведінкового } \\
\text { аналізування }\end{array}$ & $\begin{array}{l}\text { Індивідуальна оцінка } \\
\text { (максимум - 50 балів) }\end{array}$ & $\begin{array}{l}\text { Оцінка керівником } \\
\text { (максимум - 50 балів) }\end{array}$ \\
\hline К1 & 1) повагу до гідності інших осіб; & 10 & 10 \\
\hline К2 & $\begin{array}{l}\text { 2) ввічливість та дотримання } \\
\text { високої культури спілкування; }\end{array}$ & 10 & 10 \\
\hline К3 & $\begin{array}{l}\text { 3) доброзичливість і запобігання } \\
\text { виникненню конфліктів у } \\
\text { стосунках з громадянами; }\end{array}$ & 10 & 10 \\
\hline
\end{tabular}




\begin{tabular}{|c|c|c|c|}
\hline K4 & $\begin{array}{l}\text { 4) недопущення, у тому числі } \\
\text { поза державною службою, дій і } \\
\text { вчинків, які можуть зашкодити } \\
\text { інтересам державної служби чи } \\
\text { негативно вплинути на репутацію } \\
\text { державного службовця. }\end{array}$ & 5 & 5 \\
\hline K5 & $\begin{array}{l}\text { 5). сумлінність, компетентність, } \\
\text { результативність, відповідальність } \\
\text { та неупередженість у виконанні } \\
\text { своїх посадових обов’язків, } \\
\text { ініціативність, а також не } \\
\text { допускання ухилення від прийняття } \\
\text { рішень та відповідальності за свої } \\
\text { дії та рішення. }\end{array}$ & 5 & 5 \\
\hline K6 & $\begin{array}{l}\text { 6). Удосконалення свої х умінь, } \\
\text { знань i навичок відповідно до } \\
\text { функцій та завдань займаної } \\
\text { посади, підвищення професійного } \\
\text { та культурного рівня, }\end{array}$ & 5 & 5 \\
\hline K7 & $\begin{array}{l}\text { 7)Виконання додаткових завдань } \\
\text { (у випадку відсутності іншого } \\
\text { працівника), } \\
\text { кваліфікації, стажування }\end{array}$ & 5 & 5 \\
\hline & & бегуючі коефіцієнти & \\
\hline P1 & $\begin{array}{l}\text { Коефіцієнт врахування скарг } \text { на } \\
\text { роботу органів публічної влади }\end{array}$ & $\begin{array}{c}0 \text { скарг } \\
1 \text { скарга, яка доводить } \\
\text { порушення/некомпетент } \\
\text { ність ДС -0,8 } \\
2 \text { скарги, яка доводить } \\
\text { порушення/некомпетент } \\
\text { ність ДС }-0,75 \\
\end{array}$ & $\begin{array}{c}0 \text { скарг } \\
1 \text { скарга, яка доводить } \\
\text { порушення/некомпетентніс } \\
\text { ть ДС - } 0,8 \\
2 \text { скарги, яка доводить } \\
\text { порушення/некомпетентніс } \\
\text { ть ДС }-0,75 \\
\end{array}$ \\
\hline $\mathrm{P} 2$ & $\begin{array}{l}\text { Наявність справ про дисциплінарні } \\
\text { порушення }\end{array}$ & $\begin{array}{c}\text { немає -1 } \\
\text { була, але вина комісією } \\
\text { не доведена -0,95 } \\
\text { дисциплінарні } \\
\text { стягнення: } \\
\text { зауваження -0,8 } \\
\text { попередження про } \\
\text { неповну службову } \\
\text { відповідність - } 0,7 \\
\end{array}$ & $\begin{array}{c}\text { немає -1 } \\
\text { була, але вина комісією не } \\
\text { доведена -0,95 } \\
\text { дисциплінарні стягнення: } \\
\text { зауваження -0,8 } \\
\text { попередження про неповну } \\
\text { службову відповідність - } \\
0,7\end{array}$ \\
\hline P3 & $\begin{array}{lr}\text { Наявність } & \text { внутрішньо- } \\
\text { корпоративних } & \text { конфліктів/скарги } \\
\text { колег по роботі } & \end{array}$ & & $\begin{array}{c}\text { немає -1 } \\
\text { скарги 3-х колег -0,85 } \\
\text { скарги 3-5 колег -0,8 } \\
\text { скарги 6-7 колег - } 0,7 \\
\text { Більше скарг потребує } \\
\text { внутрішнього } \\
\text { розслідування } \\
\end{array}$ \\
\hline \multicolumn{2}{|c|}{ Розрахункова формула: } & \multicolumn{2}{|c|}{$R=\left(\Sigma_{1}^{7} K_{i}\right) \times P 1 \times P 2 \times P 3(1)$} \\
\hline \multicolumn{2}{|c|}{$\begin{array}{l}\text { Максимальна кількість балів } 3 \text { оцінювання за } \\
\text { двома критеріями } \boldsymbol{R}\end{array}$} & \multicolumn{2}{|c|}{100} \\
\hline \multicolumn{4}{|c|}{ Значення індексу професійної якості державного службовця } \\
\hline \multicolumn{2}{|c|}{ Проміжок балів } & \multicolumn{2}{|c|}{ Опис } \\
\hline \multicolumn{2}{|c|}{ 90-100 балів } & \multicolumn{2}{|c|}{$\begin{array}{c}\text { Висока якість професійної етики, що слід врахувати } \\
\text { при врахування на різні види матеріальної і } \\
\text { матеріальної мотивації, а також при складанні } \\
\text { рекомендацій стосовно зміни рангу чи посади }\end{array}$} \\
\hline
\end{tabular}




\begin{tabular}{|l|c|}
\hline $80-89$ балів & $\begin{array}{c}\text { Достатня якість професійної етики, при цьому } \\
\text { необхідно мотивувати нематеріальними методами }\end{array}$ \\
\hline $70-79$ балів & Середня якість професійної етики, що потребує \\
& детальнішого аналізування поведінки державного \\
& службовця шляхом проведення додаткового \\
& анкетування та бесід \\
\hline $60-69$ балів & Низька якість професійної етики, що потребує \\
& детальнішого аналізування поведінки державного \\
& службовця шляхом проведення бесід про \\
& можливість дисциплінарного розслідування \\
\hline
\end{tabular}

Примітка: Складено та сформовано авторами

Так, встановлено, що використання запропонованої моделі дасть змогу досить швидко i ефективно знаходити тих кандидатів, які найбільше підходять для конкретного робочого місця. Своєю чергою це призведе і до зниження корупційних ризиків, плинності кадрів, а також до економії значної кількості часу на проведення підбору персоналу.

Висновки. Ще у 2016 році Національним агенством України з питань державної служби було розроблено наказ «Про затвердження Загальних правил етичної поведінки державних службовців та посадових осіб місцевого самоврядування» [1], проте цей документ досі не доповнено санкціями за порушення даних норм.

Стосовно контролю за дотриманням етики в сфері державної служби: необхідно створити алгоритм розгляду пропозицій i скарг громадян, процедури моніторингу робочого клімату в колективі, визначити структуру, яка могла б здійснювати контроль за виконанням положень кодексу, розробити санкції за неналежну службову поведінку та механізм вирішення конфліктних ситуацій та проходження службових викриттів.

Слід зауважити, що для формування сучасної ефективної державної служби необхідно постійно працювати з людським активом і здійснені в дослідженні пропозиції не $є$ вичерпними, проте можуть слугувати ефективним інструментів для виявлення $\mathrm{i}$ попередження професійних ризиків, які можуть призвести до негативних макроекономічних наслідків.

Результатами дослідження стало побудова методології та моделі поведінкового аналізування. На основі запропонованої методології шляхом проведення опитування було встановлено пріоритетність видів нематеріальних мотивів для окремих вікових груп. Запропонована методологія дослідження пріоритетності нематеріального мотивування та система опитування державних службовців-початківців, розроблені на основі застосування професіограми та психограми, значною мірою дозволить вчасно виявити елементи неетичної поведінки і забезпечити мінімізацію корупційних ризиків.

Установлено, що застосування поведінкового аналізу має теоретичне і прикладне значення. Результати теоретико-емпіричного дослідження теорій поведінкового аналізу дали можливість застосувати його у діяльності державих службовців. Використання методики «Шкала можливостей i потреб» та «Оцінка ділових якостей» дозволило вибудувати «портрет 
державного службовця» до і після здійснення розстановок та розподілу ролей.

Підсумовуючи результати наукового пошуку акторками було запропоновано модель поведінкового аналізування державних службовців, яка включає сім оціночних показників та три коригуючих коефіцієнтів, використовуваних для встановлення індексу професійної якості державного службовця.

В перспективі авторками планується розробити загальну модель оцінки ефективності роботи роботи державних службовців категорій Б та В, котра включала б показники ефективності робти, тобто наскільки ефективно досягаються поставлені цілі у виконанні завдань, а також і показники поведінкового аналізування та дотримання етичних норм.

\section{Лimepamypa:}

1. Про затвердження Загальних правил етичної поведінки державних службовців та посадових осіб місцевого самоврядування: наказ національного агенства України з питань державної служби від 05.08.2016, №158. URL: https://zakon.rada.gov.ua/laws/show/z120316\#Техt (дата звернення: 15.03.2021)

2. Про державну службу: Закон України від 6.03.2021, № 889-VIII. URL: https://zakon.rada.gov.ua/laws/show/889-19\#Те (дата звернення: 25.03.2021)

3. Про службу в органах місцевого самоврядування: Закон України від 15.01.2021, № 2493-III. URL: https://zakon.rada.gov.ua/laws/show/2493-14\#Text (дата звернення: 10.03.2021)

4. Про запобігання корупції: Закон України від 04.03.2021, № 1700-VII. URL : https://zakon.rada.gov.ua/laws/show/1700-18\#Tеxt (дата звернення: 15.02.2021)

5. Watson J. Psychology as the behaviorist views it. Psychological Review. 1913. 20. pp. 158-177.

6. Skinner B. The Behavior of Organisms. Appleton-CenturyCrofts. 1938. INC. pp 3-44

7. Coase R. The Nature of the Firm. Economica. 1937. Blackwell: Blackwell Publishing. pp. $386-405$

8. Coase R. The Problem of Social Cost. Journal of Law and Economics. 1960. Chicago: The University of Chicago Press, Vol. 3 (Oct., 1960). pp. 1-44

9. Coase R. Ideas, Their Origins and Their Consequence. American Enterprise Institute for Public Policy Research. 1988. New York. 421 p.

10. Downs A. An Economic Theory of Democracy. 1957. New York, Harper. 345 p.

11. Buchanan J, Tullock G. The Calculus of Consent. 1962. Michigan: University of Michigan Press, 557 p.

12. Olson M. The Logic of Collective Action. 1965). Cambridge, Mass.: Harvard University Press. 185 p.

13. Taler R. Nudge: Improving Decisions About Health, Wealth and Happiness. 2008. Yale: New Heaven\&London: Yale University Press. 220 p.

14. Плешакова Е., Азимина Е. Поведенческие характеристики российских государственных служащих и их влияние на эффективность государственного управления. Общество: политика, экономика, право. 2016. 11. С. 25-28 $688 \mathrm{c}$.

15. Рубинштейн С. Основы общей психологии. Санкт Петербург: Питер Ком. 1998.

16. Пряжников Н., Пряжникова Е. Психология труда: учеб. пособие для студ. высш. учеб. Заведений. 5-е изд., стер. Москва: Издательский центр «Академия». 2009.480 с.

17. Оболенський О. Державна служба: навч. посіб. Київ: КНЕУ. 2003. 344 с. 
18. Малімон Л. Психологічний аналіз значущості та задоволеності мотивів професійної діяльності державних службовців місцевих органів виконачої влади. Том 1 : Організаційна психологія. Економічна психологія. Соціальна психологія. Вип. 37-38. Збірник наукових праць / За ред. С.Д. Максименка, Л.М. Карамушки. Алчевськ: ЛАДО, 2013. C. 56-61.

19. Литвиновська I., Литвиновський $€$. Феномен лідерства на державній службі. Науковий вісник: Державне управління, 2021, №1(7), C. 162-180. URL: https://nvdu.undicz.org.ua/index.php/nvdu/article/view/148/153 (дата звернення: 09.04.2021)

20. Люхтерхандт О. Експертний висновок щодо проекту «Концепція реформи адміністративного права України». Адміністративна реформа в Україні : Документи $і$ матеріали. Укр. правоий часопис. 1999. Вип. 4. С. 92-106.

21. Професіограма державного службовця. Кафедра менеджменту і публічного адміністрування ХНУМГ ім. О.М.Бекетова: веб сайт. URL:

https://mmgh.kname.edu.ua/index.php/19-abiturientam/262-profesiograma-derzhavnogosluzhbovtsya (дата звернення: 29.03.2021)

22. Dongye Zhang, Shun Zhang. Psychological analysis on civil servants committing immoral behavior. Revista Argentina de Clínica Psicológica. 2020. Vol. XXIX. №1. pp. 942-948

23. The six boxes model. The performance thinking network: web site. URL: https://www.sixboxes.com/Six-Boxes-Model.html? (дата звернення: 8.04.2021)

\section{References:}

1. Pro zatverdzhennia Zahalnykh pravyl etychnoi povedinky derzhavnykh sluzhbovtsiv ta posadovykh osib mistsevoho samovriaduvannia: nakaz natsionalnoho ahenstva Ukrainy z pytan derzhavnoi sluzhby [About the statement of the General rules of ethical behavior of civil servants and officials of local government: the order of the national agency of Ukraine concerning civil service] from 05.08.2016, №158 (2021, August 5). Retrived from: https://zakon.rada.gov.ua/laws/show/z1203-16\#Text [in Ukrainian]

2. Pro derzhavnu sluzhbu: zakon Ukrainy [On Civil Service: Law of Ukraine] from 6.03.2021, № 889-VIII. (2021, March 6). Retrived from: https://zakon.rada.gov.ua/laws/show/889-19\#Te [in Ukrainian]

3. Pro sluzhbu v orhanakh mistsevoho samovriaduvannia: Zakon ukrainy [On service in local self-government bodies: Law of Ukraine] from 15.01.2021, № 2493-III. (2021, February 15). Retrived from: https://zakon.rada.gov.ua/laws/show/2493-14\#Text [in Ukrainian]

4. Pro zapobihannia koruptsii: Zakon Ukrainy [On Prevention of Corruption: Law of Ukraine] from 04.03.2021, № 1700-VII. (2021, March 4). Retrived from:: https://zakon.rada.gov.ua/laws/show/1700-18\#Text [in Ukrainian]

5. Watson, J. (1913). Psychology as the behaviorist views it. Psychological Review, 20, 158-177. [in English]

6. Skinner B. (1938), The Behavior of Organisms. Appleton-CenturyCrofts, New York: INC., 3-44 [in English]

7. Coase R. (1937). The Nature of the Firm». Economica. Blackwell: Blackwell Publishing. 386-405 [in English]

8. Coase R. (1960). The Problem of Social Cost. Journal of Law and Economics. Chicago: The University of Chicago Press, Vol. 3 (Oct., 1960). 1-44 [in English]

9. Coase R. (1988). Ideas, Their Origins and Their Consequence. New York. American Enterprise Institute for Public Policy Research [in English]

10. Downs A. (1957). An Economic Theory of Democracy. New York, Harper [in English]

11. Buchanan J, Tullock G. (1962). The Calculus of Consent. Michigan: University of Michigan Press [in English]

12. Olson M. (1965). The Logic of Collective Action. Cambridge, Mass.: Harvard University Press [in English] 
13. Taler R. (2008). Nudge: Improving Decisions About Health, Wealth and Happiness. Yale:Yale University Press, New Heaven\&London [in English]

14. Pleshakova E., Azymyna E. (2016). Povedencheskye kharakterystyky rossyiskykh hosudarstvennыkh sluzhashchykh y ykh vlyianye na эffektyvnost hosudarstvennoho upravlenyia [Behavioral characteristics of Russian civil servants and their influence on the efficiency of public administration] Obshchestvo: polytyka, эkonomyka, pravo. 11. 25-28 [in Russian]

15. Rubynshtein S. (1998). Osnovi obshchei psykholohyy [Fundamentals of general psychology]. - Sankt Peterburg: Pyter Kom [in Russian]

16. Pryazhnikov N., Pryazhnikova E. (2009). Psykholohyia truda: ucheb. posobye dlia stud. [Psychology of work: textbook. manual for stud]. Moskov: Publishing Center "Academy" [in Russian]

17. Obolenskyi O. (2003). Derzhavna sluzhba: navch. Posib [Civil service: textbook]. Kyiv: KNEU n Ukrainian]

18. Malimon L. (2013). Psykholohichnyy analiz znachushchosti ta zadovolenosti motyviv profesiynoyi diyal'nosti derzhavnykh sluzhbovtsiv mistsevykh orhaniv vykonachoyi vlady [Psychological analysis of the significance and satisfaction of the motives of professional activity civil servants of local executive bodies]. Aktual'ni problemy psykholohiyi. Vol 1. 37-38. Alchevs'k : LADO. pp. 56-61.

19. Lytvynovska I., Lytvynovskyi Ye. (2021). Fenomen liderstva na derzhavnii sluzhbi [The phenomenon of leadership in the civil service]. Naukovyi visnyk: Derzhavne upravlinnia. №1(7). 162-180. Retrived from: https://nvdu.undicz.org.ua/index.php/nvdu/article/view/148/153 [in Ukrainian)

20. Liukhterkhandt O. (1999). Ekspertnyi vysnovok shchodo proektu «Kontseptsiia reformy administratyvnoho prava Ukrainy» [Expert opinion on the project "Concept of Administrative Law Reform of Ukraine"]. Administratyvna reforma $v$ Ukraini : Dokumenty $i$ materialy. Ukrainskyi pravovyi chasopys. Vol. 4. 92-106. [in Ukrainian]

21. Profesiohrama derzhavnoho sluzhbovtsia (2019). Kafedra menedzhmentu i publichnoho administruvannia KhNUMH im. O.M.Beketova [Department of Management and Public Administration KhNUMG]. Retrived from: https://mmgh.kname.edu.ua/index.php/19abiturientam/262-profesiograma-derzhavnogo sluzhbovtsya [in Ukrainian]

22. Dongye Zhang, Shun Zhang (2020). Psychological analysis on civil servants committing immoral behavior. Revista Argentina de Clínica Psicológica. Vol. XXIX. №1. 942948 [in English]

23. The six boxes model (2012). The performance thinking network. Retrived from: https://www.sixboxes.com/Six-Boxes-Model.html? [in English] 